\title{
Intermediate pilomyxoid astrocytoma and diencephalic syndrome: imaging findings
}

\author{
Astrocitoma pilomixoide intermediário e síndrome diencefálica: aspectos de imagem
}

\author{
Olavo Kyosen Nakamura ${ }^{1}$, Marco da Cunha Pinho ${ }^{1}$, Vicente Odone Filho ${ }^{2}$, Sergio Rosemberg ${ }^{3}$
}

\begin{abstract}
Pilomyxoid astrocytoma, an entity described as a histological variant of pilocytic astrocytoma, is a rare primary tumor of the central nervous system. It is usually located in the hypothalamic-chiasmatic area, affecting children with a mean age of 10 months. It has a high rate of recurrence and cerebrospinal fluid dissemination, which may be present throughout the neuroaxis. Due to its topography, it may present developmental delay in childhood and diencephalic syndrome, characterized by extreme weight loss, lack of fat accumulation, hyperactivity, euphoria and alertness. Magnetic resonance imaging has an important role in its diagnosis, staging and follow-up of pilomyxoid astrocytoma. However, for a definitive diagnosis, anatomopathology is particularly important to differentiate it from pilocytic astrocytoma. Some cases, as in this present one, have simultaneous histological features of pilocytic and pilomyxoid astrocytomas, constituting a group called intermediate pilomyxoid astrocytoma. Surgery is the best treatment option and it usually requires adjuvant therapy.
\end{abstract}

Keywords: Astrocytoma/diagnosis; Astrocytoma/pathology; Diencephalon; Magnetic resonance imaging; Child; Case reports

\section{RESUMO}

0 astrocitoma pilomixoide, entidade descrita como variante histológica do astrocitoma pilocítico, é um raro tumor primário do sistema nervoso central. Geralmente, localiza-se em topografia hipotálamoquiasmática, acomentendo crianças com idade média de 10 meses. Apresenta alta taxa de recorrência e disseminação liquórica, podendo se apresentar ao longo de todo o neuroeixo. Dada sua topografia, pode se apresentar com atraso do desenvolvimento na infância e síndrome diencefálica, caracterizada por emagrecimento extremo, ausência de acúmulo de tecido adiposo, hiperatividade motora, euforia e estado de alerta. A ressonância magnética possui um papel importante para o diagnóstico, estadiamento e seguimento do astrocitoma pilomixoide. No entanto, para o diagnóstico definitivo, o estudo anatomopatológico é fundamental, principalmente na diferenciação com 0 astrocitoma pilocítico. Além disso, em alguns casos, como o aqui apresentado, evidencia-se a apresentação simultânea de características histológicas do astrocitoma pilomixoide e pilocítico, constituindo um grupo denominado astrocitoma pilomixoide intermediário. A cirurgia é a melhor opção de tratamento e geralmente há necessidade de tratamento adjuvante.

Descritores: Astrocitoma/diagnóstico; Astrocitoma/patologia; Diencéfalo; Imagem por ressonância magnética; Criança; Relatos de casos

\section{INTRODUCTION}

Pilomyxoid astrocytoma is described as a histological variant of pilocytic astrocytoma, and constitutes a rare primary tumor of the central nervous system, which is usually found at topography of hypothalamicchiasmatic $^{(1)}$, and may be recognized as the diencephalic syndrome. The diencephalic syndrome was described by Russel in $1951^{(2)}$ as one of the causes of developmental delay in childhood characterized by extreme weight loss, lack of fat accumulation, hyperactivity, euphoria and alertness ${ }^{(3)}$. This syndrome often happens associated with anterior hypothalamic tumors and third ventricle floor, involving the optic nerve and the chiasm. Astrocytomas are premoninant, however, sometimes other types of tumor are found, such as ependymomas, gangliogliomas, dysgerminoma, craniopharyngioma, among others ${ }^{(3)}$. The early symptoms often appear before the first year of life.

\footnotetext{
Department of Diagnostic Imaging, Hospital Israelita Albert Einstein - HIAE, São Paulo (SP), Brazil.

${ }^{2}$ Department of Pediatrics, Hospital Israelita Albert Einstein - HIAE, São Paulo (SP), Brazil.

${ }^{4}$ Department of Pathology, Hospital Israelita Albert Einstein - HIAE, São Paulo (SP), Brazil.

Corresponding author: Olavo Kyosen Nakamura - Avenida Albert Einstein, 627, Bloco D, $4^{\circ}$ Andar - Morumbi - Zip code: $05652-900$ - São Paulo (SP), Brazil - Phone: (55 11) 2141-4271 Email: olavo.nakamura@einstein.br

Received on: Feb 24, 2012 - Accepted on: May 8, 2012
} 


\section{CASE REPORT}

The patient, a girl of 10 months and 15 days of life, was referred to our service in July 2011 with profound deficiency to gain weight although her nutritional intake was adequate. Her linear growth was not altered, and any other associated symptoms were found. She was born from full-term pregnancy, with adequate weight for the gestational age and without adverse events. A clinical investigation was done including the magnetic resonance imaging of the skull which found

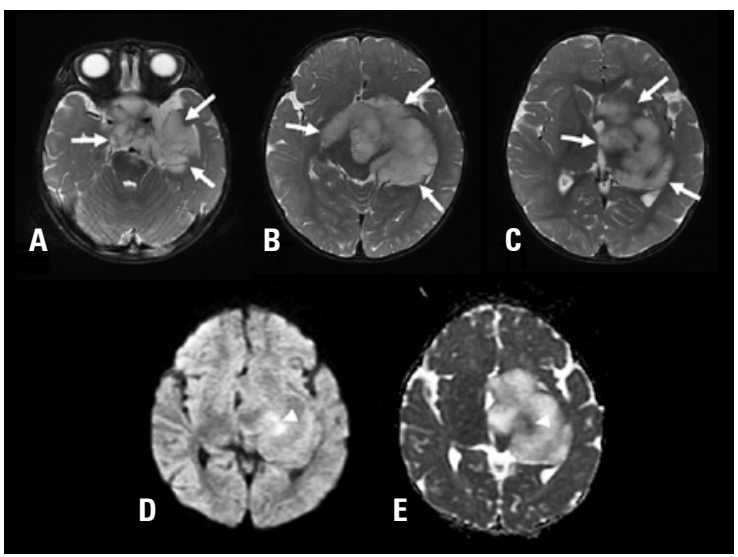

Figure 1. Magnetic ressonance imaging of the skull. T2 images with fat suppression highlighting voluminous expansive/infiltrated suprasellar formation of lobulated contour involving the optic chiasm and the optic track extending to mesial portion of temporal lobe, nucleocapsular region, thalamus, left mesencephalo and also to right anterior perforated substance, measuring about $6.8 \times 4.8 \times 3.2 \mathrm{~cm}$ at larger axis and determining the local mass effect $(A-C$, arrows). Central area poorly defined of diffusion restriction that could be related to component with high cellularity in diffusion images (D) and apparent diffusion coefficient mapping (ADC) (E)

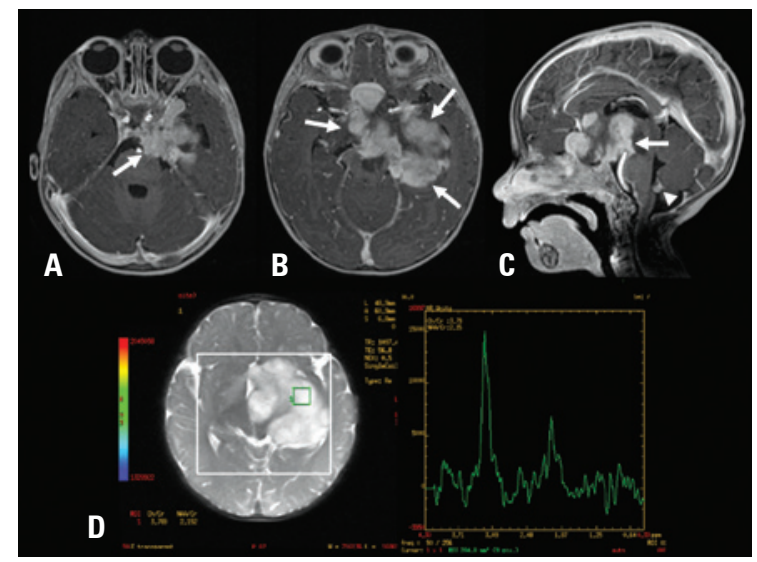

Figure 2. Magnetic resonance imaging of the skull. Images in T1 sequence after contrast injection with fat suppression highlighting intense enhancement and heterogeneous by gadolinium of voluminous mass expansive/infiltrated suprasellar (A-C, arrows) that presents extension to encephalic trunk and wide contact with basilar artery. There is a small implant inside the IV ventricle ( $\mathrm{C}$, top of the arrow) and signs of meningeal dissemination throughout the anterior pial surface of the brain trunk. The spectroscopic study (D) showed an increase of the relationship choline/ creatine (increased cell-wall turnover), decrease of the relationship N-Acetylaspartate/ Creatine (dysfunction/ neuronal depopulations) and probably lactate/lipids peak solid expansive and infiltrated lesion centered in the hypothalamus with extension to suprasellar, left mesial temporal, thalamus, internal capsule and encephalic trunk (Figures 1 and 2). We also observed nodular lesions compatible with intracranial cerebrospinal fluid dissemination in the IV ventricle and anterior surface of the tumor as well as intraspinal dissemination in D11 and D12 levels as shown in figure 3 . The biopsy of lesions was done with anatomopathological confirmation of pilomyxoid astrocytoma (Figure 4).
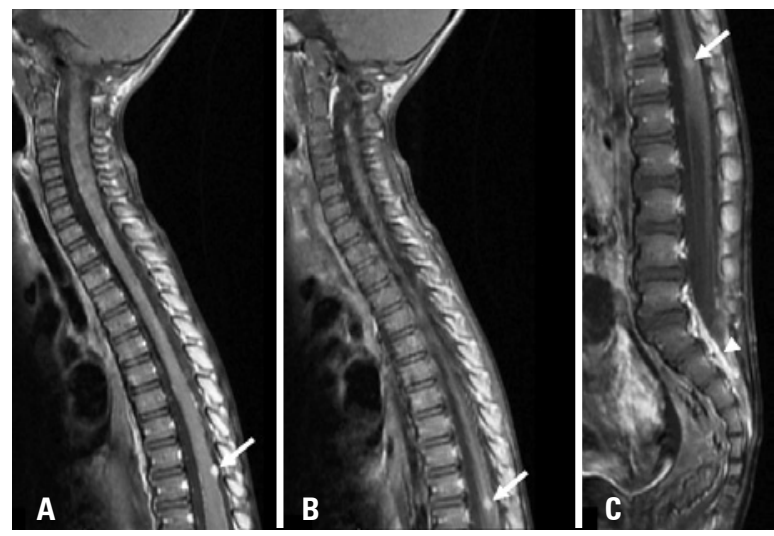

Figure 3. Magnetic resonance imaging of the spine. Images in T1 sequence after contrast injection highlighting nodular lesions compatible to dural implants located at right posterolateral height of D11, measuring $0.5 \mathrm{~cm}$ ( $\mathrm{A}$, arrow), left lateral height of $\mathrm{D} 12$, measuring $0.4 \mathrm{~cm}$ ( $\mathrm{B}$ and $\mathrm{C}$, arrow) and focus of enhancement close to cauda equina roots height of $L 2$ and $L 4$ to the right and in $L 5$ and $S 1$ ( $C$, top of the arrow)

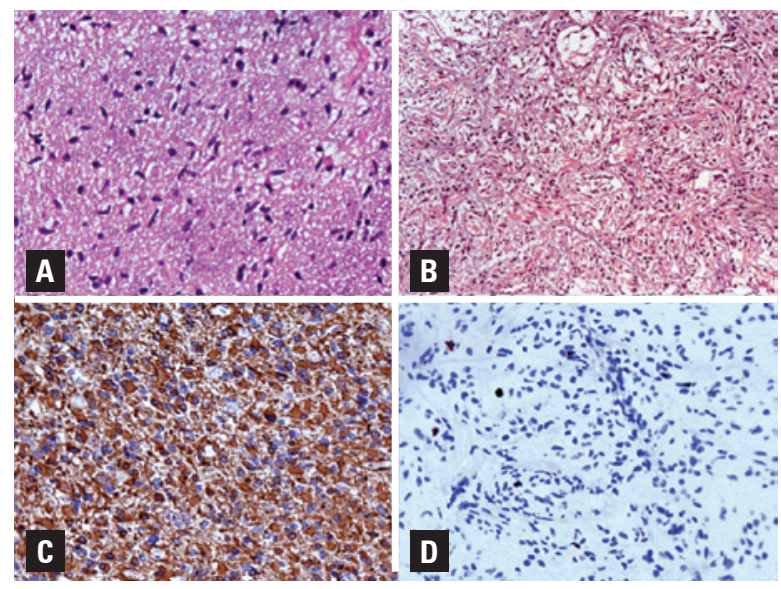

Figure 4. Pathology. Well-differentiated monomorphous astrocytic tumor constituted in part by dense fibrous tissue formed by cell with delicate and enlongated nuclei, with evident extensions $(A$, hematoxylin-eosin staining $-H E)$ and other part of the tumor presenting a loose stroma formed by elongated fibrillar cells with multipolar extensions, without specific architecture arrange, soaked in myxoid matrix ( $B, H E$ staining). The immunohistochemical showed that both tissues expressed glial fibrillary acid protein (C), and cell proliferation index was assessed by $\mathrm{KI}-67$ not overcoming $2 \%$ (D). The fibrous area is similar of those observed in pilocytic astrocytoma, although there is no Rosenthal fibers or hyaline droplets. Myxoid areas are similar of those found in pilomyxoid astrocytoma although perivascular pseudorosettes arranges were not observed. The appearance is compatible as intermediate form between pilocytic and pilomyxoid astrocytoma 


\section{DISCUSSION}

Pilomyxoid astrocytoma, an entity recently described as a histological variant of pilocytic astrocytoma, is a rare primary tumor of the central nervous system, which is usually found at topography of hypothalamicchiasmatic $^{(1)}$. It commonly affects children with mean age of 10 months, and sometimes occurs in teenagers and adults $^{(4,5)}$. In the literature the pilomyxoid astrocytoma is associated with neurofibromatosis type $\mathrm{I}^{(5)}$. Different from the good prognosis of pilocytic astrocytoma, the pilomyxoid astrocytoma is classified as type II disease by the World Health Organization, and includes high rates of recurrence and cerebrospinal fluid dissemination ${ }^{(4,5)}$. In magnetic resonance imaging studies, the pilomyxoid astrocytoma is often presented as a predominant solid mass with cystic interposed areas, hyperintense signal on $\mathrm{T} 2, \mathrm{~T} 1$ iso-signal and variable enhancement by contrast injection. It also may have cystic degeneration, necrosis or hemorrhage inside the lesion and signal of abnormality in $\mathrm{T} 2$ in adjacent deep white and gray matter ${ }^{(5-7)}$. The presence of lesion mainly solid with non-enhancing portion of the tumor, either in primary or disseminated lesions, is more common in pilomyxoid astrocytoma, which helps to differentiate it from the pilocytic astrocytoma. Non-enhancing may be related to myxoid component of lesions ${ }^{(8)}$. Other characteristics by imaging that help the differentiate diagnosis would be the predilection for suprasellar topography, intratumoral hemorrhage and leptomeningeal dissemination ${ }^{(5,8)}$. The spectroscopic showed increase of choline and lipids and decrease of creatine and N-Acetylaspartate, findings that are usually present in high grade tumors, but they are also found in pilocytic and pilomyxoid astrocytoma, which are usually considered low grade tumors ${ }^{(5)}$. The pilomyxoid astrocytoma may be present all along the neuroaxis, more commonly found in atypical topographies of older patients ${ }^{(5,7)}$. In the histological study it is characterized by prominent myxoid matrix, monomorphous angiocentric pattern and bipolar tumor cells without Rosenthal fibers and eosinophilic granular bodies $^{(4,9)}$. However, many cases show at the same time histological characteristics of pilocytic astrocytoma and also of pilomyxoid astrocytoma, so that constituting a group called intermediate pilomyxoid astrocytoma. The intermediate tumors usually present more fibers areas, biphasic architecture, Rosenthal fibers, eosinophilic granular bodies and calcifications regarding pilomyxoid tumors ${ }^{(9)}$. Surgery is the best treatment, however, the prognosis after surgery depends on the resection extension. Because its topography is generally suprasellar, there is a more complexity in surgery and, more often, presence of residual and disseminated disease. In most of the cases the adjuvant treatment with radiotherapy and chemotherapy is required ${ }^{(8,10)}$.

\section{REFERENCES}

1. Tihan T, Fisher PG, Kepner JL, Godfraind C, McComb RD, Goldthwaite PT, et al. Pediatric astrocytomas with monomorphous pilomyxoid features and a less favorable outcome. J Neuropathol Exp Neurol. 1999;58(10):1061-8.

2. Russell A. A diencephalic syndrome of emaciation in infancy and childhood. Arch Dis Child. 1951;26:274.

3. Poussaint TY, Barnes PD, Nichols K, Anthony DC, Cohen L, Tarbell NJ, et al. Diencephalic syndrome: clinical features and imaging findings. AJNR Am J Neuroradiol. 1997;18(8):1499-505.

4. Louis DN, Ohgaki H, Wiestler OD, Cavenee WK, Burger PC, Jouvet A, et al. The 2007 WHO classification of tumours of the central nervous system. Acta Neuropathol. 2007;114(2):97-109.

5. Linscott LL, Osborn AG, Blaser S, Castillo M, Hewlett RH, Wieselthaler N, et al. Pilomyxoid astrocytoma: expanding the Imaging spectrum. AJNR Am J Neuroradiol. 2008;29(10):1861-6.

6. Arslanoglu A, Cirak B, Horska A, Okoh J, Tihan T, Aronson L, et al. MR imaging characteristics of pilomyxoid astrocytomas. AJNR Am J Neuroradiol. 2003; 24(9):1906-8.

7. Komotar RJ, Mocco J, Jones JE, Zacharia BE, Tihan T, Feldstein NA, et al. Pilomyxoid astrocytoma: diagnosis, prognosis, and management. Neurosurg Focus. 2005;18(6A):E7.

8. Lee IH, Kim JH, Suh YL, Eo H, Shin HJ, Yoo SY, et al. Imaging characteristics of pilomyxoid astrocytomas in comparison with pilocytic astrocytomas. Eur $\mathrm{J}$ Radiol. 2011;79(2):311-6.

9. Johnson MW, Eberhart CG, Perry A, Tihan T, Cohen KJ, Rosenblum MK, et al. Spectrum of pilomyxoid astrocytomas: intermediate pilomyxoid tumors. Am J Surg Pathol. 2010;34(12):1783-91.

10. Komotar RJ, Burger PC, Carson BS, Brem H, Olivi A, Goldthwaite PT, et al. Pilocytic and pilomyxoid hypothalamic / chiasmatic astrocytomas. Neurosurgery. 2004;54(1):72-9; discussion 70-80 